\title{
Bacteriological Analysis of Water Quality in Hospital and Residential Water Supply of a Tertiary Care Hospital of Northern India
}

\author{
Shilpi Srivastava ${ }^{1}$, Alisha Singh ${ }^{1}$ and Nadeem Ahmed ${ }^{2}$ \\ ${ }^{1}$ Department of Microbiology, ${ }^{2}$ Department of Community Medicine, Integral Institute of \\ Medical Sciences, Lucknow, India \\ *Corresponding author
}

\section{A B S T R A C T}

\section{Keywords}

Water quality, Faecal coliforms, Most Probable No (MPN)

\section{Article Info}

Accepted:

17 November 2018

Available Online:

10 December 2018
Diseases due to consumption of water contaminated with microbes extract considerable morbidity and mortality. Monitoring of drinking water quality is thus of paramount importance. This study was done to assess water quality of hospital and residential water supply at our Medical Institute. Drinking water samples were collected from taps water coolers and submersible pumps and analyzed by multiple tube culture method to obtain Presumptive coliform count which is an indicator of recent faecal contamination. Most probable no (MPN) of the coliforms was used to determine if the sample was satisfactory. Out of a total of 42 samples $10(26.3 \%)$ samples were unsatisfactory and not suitable for human consumption, $5(11.90 \%)$ samples were of intermediate quality, $17(40.47 \%)$ samples were satisfactory and $10(26.3 \%)$ samples were found to be excellent. From the unsatisfactory and intermediate quality samples, E. coli was cultured from $16.6 \%$, Klebsiella from $4.2 \%$ and Pseudomonas from $14.2 \%$ of samples. Half of the municipal tap water supply samples were not fit for consumption. Ground water and water from UV filters (Aquaguard) was of good quality. Water coolers had a variable water quality.

\section{Introduction}

\section{Background}

Water is most important life sustaining force for the inhabitants of this world. But when contaminated it is also the vehicle for transmission of infection to humans across this world. Worldwide nearly a billion people use water that is not potable and 40 percent do not have living conditions that have proper sanitation. The result points to a grave public health crisis: 4,500 per day is the mortality from waterborne diseases, surpassing collectively Malaria AIDS, and tuberculosis (Pulitzer Centre, 2015). The United Nations identified improving water quality as one of the eight Millennium Development Goals. Its target is to reduce the number of people without access to safe water by $50 \%$ by 2015 (WHO, 2011).

Additionally there is evidence that water systems can be vectors for waterborne 
Hospital acquired infection (Anaisse et al., 2002). Infections with waterborne organisms such as Legionella, mycobacteria, Pseudomonas, and others cause significant morbidity and mortality, particularly in hospitalized immunocomprised patients (Decker et al., 2014). A 2003 CDC guideline highlighted practices to control waterborne HAIs (HICPAC, 2003).

Indicator organisms are commonly used to assess the microbiological quality of drinking or potable waters and fecal coliforms (FC) are the most commonly used bacterial indicator of recent fecal pollution. They may not always cause disease by themselves but are indicative of contamination by sewage which contains organisms like Hepatitis A virus, Vibrio cholerae dysentery casing bacteria like Shigella and Campylobacter, ova and cysts of intestinal parasites among others. Those at greatest risk of waterborne disease are infants and young children, people who are debilitated or living under unsanitary conditions and the elderly (WHO, Guideline of drinking water, 2011).

Thus Microbiological examinations have important role in the investigation of waterborne outbreaks. The aim of this study is to determine the bacteriological quality of drinking water sources and the extent of contamination at study area which will help in the intervention actions to be taken by the concerned bodies at our institute in district Lucknow (India).

\section{Materials and Methods}

\section{Study design}

This is a cross sectional study. The study proposal was approved by Institutional ethics committee and Institutional Research committee. This is a pilot study for this area as no such study has been done previously.

\section{Samples and study area}

Samples were collected from the hospital water supply and drinking water sources within University Campus and hospital for a period of six months from $1^{\text {st }}$ January 2017 to $30^{\text {th }}$ June 2017.

\section{Collection and transport of samples}

Heat sterilized screw capped bottles $(200 \mathrm{ml}$ capacity minimum) were taken for collection of water. At least $150 \mathrm{ml}$ of water was collected. Water was collected from 3 different sources of drinking water namely

Tap water: Water was collected only after running it from tap for 2-3 minutes. The outlet was sterilized with the flame of a spirit lamp.

Aqua guard/Water cooler: Water was collected only after running it from machine for 2-3 minutes.

Water from hand pump: Stagnant water in the outlet was flushed out by operating the pump for a few minutes.

\section{Inclusion criteria}

Any active water source which was used for drinking purpose and was being used by a fairly good number of people as a water source for drinking purpose.

Hospital associated water supply like taps in the OTs, water cooler installed in wards.

\section{Exclusion criteria}

A newly drilled hand pump or rarely used one was not sampled unless the facility had been pumped for more than 48 hours.

Samples from toilets were not taken.

Although recommendations vary, the time between sample collection and analysis 
should, in general, not exceed 6 hours, and 24 hours is considered the absolute maximum. The samples were immediately placed in a lightproof insulated box containing melting ice or ice-packs with water to ensure rapid cooling. If ice was not available, the transportation time was kept under 2 hours. It was made sure that samples were kept in the dark and that cooling was rapid. If these conditions were not met, the samples were discarded.

\section{Sample analysis}

Standard methods were used for the bacteriological examination of the samples (Britton and Greeson, 1987; American Public Health Association, 1998).

\section{Presumptive coliform count}

Multiple tube method was used for the estimation of presumptive coliform count, which is expressed as the Most Probable Number (MPN) of coliform specimen in 100 $\mathrm{mL}$ of water. Briefly MacConkey purple broth (double strength and single strength) in bottles or tubes was used. Durham's tube was used to detect production of gas. Bromocresol purple was used as indicator. Measured amount of water sample were added to tubes containing MacConkey purple broth by sterile graduated pipes. About $50 \mathrm{~mL}$ of water was added to one bottle of $50 \mathrm{~mL}$ double strength medium; 10 $\mathrm{mL}$ of water was added to all 5 tubes of $10 \mathrm{~mL}$ double strength medium; $1 \mathrm{~mL}$ of water each was added to 5 tubes of $5 \mathrm{~mL}$ single strength medium and $0.1 \mathrm{ml}$ of water each -was added to 5 tubes of $5 \mathrm{~mL}$ single strength medium (Mackie and McCartney: Practical medical microbiology).

\section{Interpretation}

An estimate of presumptive coliform count per $100 \mathrm{~mL}$ of the water was calculated from the number of tubes showing acid and gas production using McCardy's probability table.

\section{Differential coliform count (Eijkman test)}

It was done to confirm that the coliform bacilli which were detected in presumptive test were faecal E. coli.

\section{Method}

The positive tubes (of MPN) were sub cultured on lactose containing medium MacConkey agar. Lactose fermenting colonies which demonstrated positive indole test at $44^{\circ} \mathrm{C}$ were identified as faecal E. coli. Additional biochemical tests (Indole, MR, VP, Citrate utilization, Urease, Triple sugar iron test) were also set up to confirm bacteriological identity.

\section{Demonstration of recent and remote contamination}

\section{Recent contamination}

Faecal Escherichia coli is the most sensitive and best indicator of the recent human or animal faecal contamination of water as it does not survive in water for long time. It was demonstrated in water sample as it ferments lactose at $44^{\circ} \mathrm{C}$ with production of acid and gas and gives positive indole test at $44^{\circ} \mathrm{C}$.

\section{Remote contamination}

Faecal Streptococci: The presence of Faecal Streptococci in water is an indicator of remote fecal contamination. It can be either Enterococci or non-enterococcal Streptococci. Subcultures were made from positive tubes which were obtained from presumptive coliform test into tubes containing $5 \mathrm{~mL}$ of glucose azide broth and were incubated at $45^{\circ} \mathrm{C}$ for 48 hours. Presence of acid in the medium indicated faecal Streptococci. 
Clostridium perfringens: Their spores can survive for longer time in water and their presence indicates remote contamination in the water. First of all, the water sample was heated to kill all the vegetative spores of Clostridium perfringens. Then, multiple tube test was performed by sub culturing it onto Robertson cooked meat broth.

\section{Quality of water supply}

It was determined by the presumptive coliform count (Table 1).

\section{Results and Discussion}

Total 42 water samples from different water sources were collected. About 16(38\%) samples were taken from tap water, 15(36\%) samples were taken from Water cooler embedded with filters, $6(14 \%)$ samples were taken from Submersible pumps and 5(12\%) samples were taken from Aqua guard embedded with UV filters. Out of the total samples $(n=42) \quad 10(26.3 \%)$ samples were unsatisfactory and not suitable for human consumption whereas, 5 (11.90\%) samples were of intermediate quality, $17(40.47 \%)$ samples were satisfactory and 10(26.3\%) samples were found to be excellent (Table 2 and Fig. 1). It is to be noted that the number of unsatisfactory sample is zero for Aqua guard and Submersible pumps whereas the tap water is most contaminated as 8 samples were found to be unsatisfactory. E. coli, Klebsiella and Pseudomonas were isolated on final analysis of the samples which were not satisfactory. Of the five intermediate quality samples, three samples grew E. coli and two Pseudomonas species (Table 3 and 4).

Table.1 Grading of water Quality (Mackie and MacCarteny, 14th edition)

\begin{tabular}{|l|c|c|}
\hline Grade of water sample & $\begin{array}{c}\text { Presumptive coliform count } \\
\text { (MPN)/100 ml }\end{array}$ & E. coli count/100 ml \\
\hline Excellent & 0 & 0 \\
\hline Satisfactory & $1-3$ & 0 \\
\hline Intermediate & $4-9$ & 0 \\
\hline Unsatisfactory & $>10$ & $>1$ \\
\hline
\end{tabular}

Table.2 Comparison of the quality of samples with the site of collection

\begin{tabular}{|c|c|c|c|c|c|}
\hline Site of Sampling & $\begin{array}{c}\text { Unsatisfactory } \\
\text { No (\%) }\end{array}$ & $\begin{array}{c}\text { Intermediate } \\
\text { No }(\%)\end{array}$ & $\begin{array}{c}\text { Satisfactory } \\
\text { No }(\%)\end{array}$ & $\begin{array}{c}\text { Excellent } \\
\text { No }(\%)\end{array}$ & $\begin{array}{c}\text { Total } \\
\text { samples No }\end{array}$ \\
\hline $\begin{array}{c}\text { UV filter(Aqua } \\
\text { guard) }\end{array}$ & $\mathbf{0 ( 0 )}$ & $\mathbf{0 ( 0 )}$ & $\mathbf{1 ( 2 0 \% )}$ & $\mathbf{4 ( 8 0 \% )}$ & $\mathbf{5}$ \\
\hline $\begin{array}{c}\text { Submersible } \\
\text { pumps }\end{array}$ & $\mathbf{0 ( 0 )}$ & $\mathbf{0 ( 0 )}$ & $\mathbf{0 ( 0 )}$ & $\mathbf{6 ( 1 0 0 \% )}$ & $\mathbf{6}$ \\
\hline $\begin{array}{c}\text { Water cooler } \\
\text { fitted with filter }\end{array}$ & $\mathbf{2 ( 1 3 . 3 )}$ & $\mathbf{4 ( 2 6 . 6 )}$ & $\mathbf{9 ( 6 0 )}$ & $\mathbf{0 ( 0 )}$ & $\mathbf{1 5}$ \\
\hline Tap water & $\mathbf{8 ( 5 0 )}$ & $\mathbf{1 ( 6 . 2 5 )}$ & $\mathbf{7 ( 4 3 . 7 )}$ & $\mathbf{0 ( 0 )}$ & $\mathbf{1 6}$ \\
\hline Total & $\mathbf{1 0 ( 2 3 . 8 )}$ & $\mathbf{5 ( 1 1 . 9 )}$ & $\mathbf{1 7 ( 4 0 )}$ & $\mathbf{1 0}(\mathbf{2 3 . 8})$ & $\mathbf{4 2}$ \\
\hline
\end{tabular}


Table.3 MPN No. of the unsatisfactory samples obtained from TAP WATER along with the site of collection

\begin{tabular}{|c|l|c|}
\hline Site & Type & MPN \\
\hline NICU & Tap Water & $\mathbf{1 0}$ \\
\hline Academic block & Tap Water & $\mathbf{1 4}$ \\
\hline Girls hostel & Tap Water & $\mathbf{1 6}$ \\
\hline ICCU & Tap Water & $\mathbf{1 4}$ \\
\hline MICU & Tap Water & $\mathbf{1 9}$ \\
\hline Blood Bank & Tap Water & $\mathbf{2 4}$ \\
\hline Emergency ward & Tap Water & $\mathbf{3 8}$ \\
\hline Wash Basin(Hospital) & Tap Water & $\mathbf{4 9}$ \\
\hline
\end{tabular}

Table.4 Microbes isolated from the unsatisfactory and intermediate quality samples

\begin{tabular}{|c|c|c|c|c|c|c|}
\hline \multirow{2}{*}{$\begin{array}{l}\text { Source of } \\
\text { water } \\
\text { sample }\end{array}$} & \multirow{2}{*}{$\begin{array}{l}\text { No. of } \\
\text { sample } \\
\text { collected } \\
\text { No }(\%)\end{array}$} & \multirow{2}{*}{$\begin{array}{c}\text { No. of } \\
\text { Unsatisfacto-ry } \\
\text { samples } \\
\text { No }(\%)\end{array}$} & \multirow{2}{*}{$\begin{array}{c}\text { No of } \\
\text { Intermediate } \\
\text { quality } \\
\text { samples } \\
\text { No (\%) }\end{array}$} & \multicolumn{3}{|c|}{ Organism Grown } \\
\hline & & & & $\begin{array}{l}\text { E. coli } \\
\text { No }\end{array}$ & $\begin{array}{c}\text { Klebsiella sp. } \\
\text { No }\end{array}$ & $\begin{array}{c}\text { Pseudomonas sp. } \\
\text { No }\end{array}$ \\
\hline $\begin{array}{c}\text { Submersibl } \\
\mathrm{e}\end{array}$ & $\begin{array}{c}6 \\
(14.2 \%)\end{array}$ & $\mathbf{0}(\mathbf{0})$ & $\mathbf{0}$ & - & - & - \\
\hline Tap water & $16(38 \%)$ & $8(50 \%)$ & 1 & 3 & 1 & $4+1 *$ \\
\hline $\begin{array}{l}\text { Water } \\
\text { cooler }\end{array}$ & $\begin{array}{c}15 \\
(35.7 \%)\end{array}$ & $2(13.33 \%)$ & 4 & $1+3 *$ & 1 & $1 *$ \\
\hline $\begin{array}{l}\text { UV } \\
\text { filter(Aqua } \\
\text { guard) }\end{array}$ & $\begin{array}{c}5 \\
(11.9 \%)\end{array}$ & $\mathbf{0}(\mathbf{0})$ & $\mathbf{0}$ & - & - & - \\
\hline Total & 42 & $10(23.8)$ & 5(11.9) & $7(16.6)$ & $2(4.7)$ & $6(14.2)$ \\
\hline
\end{tabular}

*numbers in blue are of intermediate quality samples

Fig.1 Bacteriological quality of the water samples

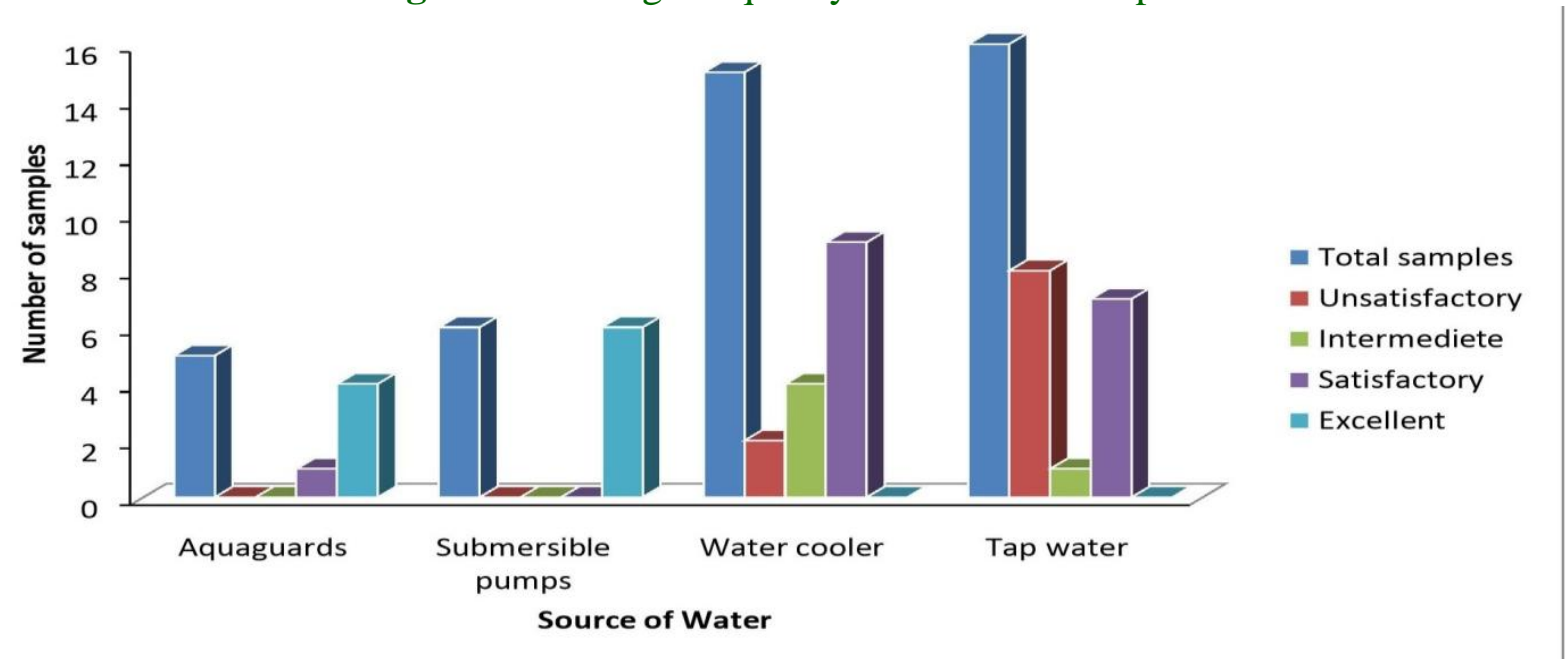


Many diseases affecting mankind are only due to consumption of contaminated water or raw food washed with dirty water. WHO (2010) reports that over 2.6 billion people lack access to clean water, which is responsible for about 2.2 million deaths annually, of which 1.4 million are in children. Improving water quality can reduce the global disease burden by approximately $4 \%$. Monitoring the levels of indicator organisms (such as faecal coliforms, E. coli) is a common approach for quantifying the potential pathogen present in a source of drinking water. Studies have evaluated water quality by enumerating fecal coliforms and $E$. coli levels in rivers, lakes, estuaries, and coastal waters (Pandey et al., 2012a; Pandey et al., 2012b).

In this study we found that there was evidence of recent faecal contamination in about $25 \%$ of samples which were unfit for human consumption. There was no evidence of any remote faecal contamination in the samples analysed. Over half of tap water samples were unsatisfactory and not fit for use as drinking water. No tap water sample was of excellent quality. Of the unsatisfactory quality samples $40 \%$ grew E. coli, $10 \%$ Klebsiella species and $40 \%$ samples were contaminated with Pseudomonas species. Of the five intermediate quality samples, three samples grew E. coli and two Pseudomonas species. This data shows that the municipal supply of water has fluctuating quality. Either some water pipelines are damaged and contaminated with sewage water or the filteration and chlorination treatment of water is not adequate. Similar findings have been reported by Shamsi et al., (2015) from Fatehgarh (U.P). In about one hundred water samples collected from tap water, handpump and water coolers, the authors found that almost half of the samples were unsatisfactory. E. coli was cultured from $26 \%$ of samples and Pseudomonas from $20 \%$ of collected samples. In a study done in Merrut on drinking water samples, over $69 \%$ tap water samples and $70 \%$ of cooler water were unsatisfactory. Organism identified were Escherichia coli (28\%), Klebsiella sp. (15\%) and Pseudomonas sp. (25\%) in total positive samples (Kumar et al., 2013). The MPN number of some samples was very high $(\geq$ 180). In this study the MPN no ranged from 10 to 49 among the tap water samples.

Compared to tap water the untreated water of rivers springs and ponds is now highly contaminated. One study on such sources in field areas has reported MPN count more than 1600 in some cases (Goel et al., 2007). Microbial contamination of ground water sources can be a problem in urban areas also. In a study done in Mardan, Pakistan on samples of wells and tube wells, faecal coliform were found in $90 \%$ samples and $E$. coli in 56\% samples. The (MPN) ranged from 40 to as high as 2400 (Khan et al., 2012). In contrast in our study water samples from the submersible pump accessing the ground water were of excellent quality. Also water filtered by standalone Aquaguard (UV light based) filter was mostly of excellent quality. All samples were fit for consumption.

In comparison water from water coolers fitted with aquaguard had variable quality with two out of fifteen samples showing unsatisfactory result and four were of intermediate quality. This data throws light on a very important but often missed parameter that is storage of potable water. Even though the water was filtered, it became contaminated due to deficient cleaning of storage tank or improper use of the faucets. There is still need of creating awareness for cleaning of storage vessels and tanks. Another factor to be noted was that the intermediate quality though had a low MPN, yet came positive for $E$. coli on culture.

Pseudomonas species was cultured from six hospital supply samples. Pseudomonas has 
the propensity to form biofilms and may have colonized the faucets. This finding is significant as an association between Pseudomonas aeruginosa infections and water sources has been found (Cervia, 2012). Pseudomonas aeruginosa causes infections generalized by inflammation and sepsis, which can be fatal if colonization occurs in critical body organs, such as the lungs, urinary tract or kidneys. There is plenty of evidence associating P. aeruginosa infections and tap water used in the intensive care unit (ICU) and patient rooms (Trautman et al., 2001; Reuter et al., 2002). In a study using genetic-based epidemiological evidence association was found between P. aeruginosa and waterborne HAIs. Over a six-month period, 19 out of 38 patient infections were acquired via tap water or cross-transmission (Roques et al., 2007). There has been a difference of opinion on the current indicator organisms and their ability to represent the source of faecal contamination as human vs animal excreta and bird droppings Microbial source tracking to trace the origin of faecal coliform is a new approach that holds promise. (Grave et al., 2007; Dickerson et al., 2007)

This study concludes that the tap water supply is not potable in about half of the samples. UV filters should be used at point source of drinking and hospital supply. The ground water is not contaminated in our area. We recommend that potable water supply for drinking purposes and for washing in hospitals and residences should be analysed bacteriologically at regular intervals so that feedback could be given to the concerned authorities.

\section{Acknowledgement}

The authors would like to acknowledge $\mathrm{Mr}$ Ayub Khan, Supervisor for help in collection of samples.

\section{References}

American Public Health Association (APHA, 1998), and Water Pollution Control Federation, Standard methods for the examination of water and waste water 20 th ed, Washington D.C, (1998).

Anaissie, E.J, Penzak, S.R. and Dignani, M.C. 2002. The hospital water supply as a source of nosocomial infections: a plea for action. Arch Intern Med, 162:148392.

Britton, L.J., Greeson, P.E. 1987. Methods for collection and analysis of aquatic biological and microbiological samples; US Geological survey techniques of water-resources investigations, book 5, chap., A4, 363-403.

Cervia, J. 2012. Keeping a float in a rising tide of waterborne HAIs: 8 Facts healthcare leaders must know. Infection Control Today (http://www.infection controltoday.com/articles/2012).

Decker, B.K and Palmore, T.N.2014. Hospital water and opportunities for infection prevention. Current infectious disease reports. $16 \quad$ (10):432. doi:10.1007/s11908-014-0432-y.

Dickerson, J.W., Crozier, J.B., Hagedorn, G and Hassall, A. 2007. Assessment of 16 $\mathrm{s}-23 \mathrm{~s}$ rDNA interagenic spacer regions in Enterococcus spp. for microbial source tracking. J Environ Qual 36:1661-1669.

Goel. S., Sood, R., Mazta, S., Bansal, P and Gupta, A. 2007. Bacteriological quality of water samples of a tertiary care medical centre campus in North West Himalayan region of India. Internet journal of Third world Medicine 2007; 5(1): 5 .

Grave, A.K., Hagedorn, C., Brooks, A., Hagedorn, R.L and Martin, E (2007) Microbial source tracking in a rural watershed dominated by cattle. Water Res 41:3729-3739. 
Guidelines of drinking water quality, 4th edition, 2011.World Health Organization. ISBN 9789241548151

HICPAC, 2003; Guidelines for Environmental Infection Control in Health-Care Facilities. Recommendations of $\mathrm{CDC}$ and the healthcare infection control practices advisory committee (HICPAC).

Khan, N., Hussain, S.T., Saboor, A., Jamila, N., Ahmed, S and Riaz Ullah, R. 2012. "Bacteriological investigation of ground water sources in selected urban areas of district Mardan, Khyber Pakhtunkhwa, Pakistan". African Journal of Biotechnology. 11: (51).

Kumar, D., Malik S., Madan M. and Pandey A. 2013. Bacteriological analysis of drinking water by MPN method in a tertiary care hospital and adjoining area Western UP, India. Journal of Environmental sciences. 4(3):17-22.

Mackie and McCartney: Practical medical microbiology Eds J. G. Collee, J. P. Duguid, A. G. Fraser and B. P. Marmion, 14th edition; Churchill Livingstone (1996).

Pandey, P.K and Soupir, M.L. 2012a. Nonpoint Source Pollution. Berkshire Encyclopedia of Sustainability: Ecosystem Management and Sustainability. Berkshire Publishing Group, LLC, Great Barrington, MA, U.S

Pandey, P.K., Soupir, M.L and Rehmann C.R.2012 b. A model for predicting resuspension of Escherichia coli from streambed sediments. Water Res. 46:115-126.
Reuter S, A., Sigge, A., Wiedeck H. and Trautmann M. 2002. Analysis of transmission pathways of Pseudomonas aeruginosa between patients and tap water outlets. Crit Care Med. 30:22228.

Roques, A.M., Boulestreau, H., Lasheras, A., Boyer, A., Gruson, D., Merle, C., Castaing, Y., Bebear, C.M. and Gachie, J.P.2007. Contribution of tap water to patient colonization with Pseudomonas aeruginosa in a medical intensive care unit. J. Hosp. Infect. 67: 72-8. 2007.

Shamsi, M.S., Goel, S., Singh, A., Gupta, A., Mirza, R.U.B Jai Krishna et al., 2015. An evaluation of bacteriological quality of drinking water from the catchment area of a tertiary care teaching hospital. IAIM. 2(7): 76-81. Page 81

Trautmann, M., Michalsky, T., Wiedeck, H., Radosavljevic, V. and Ruhnke, M. 2001. Tap water colonization with Pseudomonas aeruginosa in a surgical intensive care unit (ICU) and relation to Pseudomonas infections of ICU patients. Infect Control Hosp Epidemiol. 22:49-52

Water and Sanitation: Pulitzer Center on Crisis Reporting, 2015.

WHO (2011) Millennium Development Goals: progress towards the healthrelated Millennium Development Goals., http://www.who.int/media centre/factsheets/fs290/en/index.html. Accessed 25 June 2012

World Health Organization (WHO) (2010) Water Sanitation and Health, http://

www.who.int/water_sanitation_health/disease s/en/

\section{How to cite this article:}

Shilpi Srivastava, Alisha Singh and Nadeem Ahmed. 2018. Bacteriological Analysis of Water Quality in Hospital and Residential Water Supply of a Tertiary Care Hospital of Northern India. Int.J.Curr.Microbiol.App.Sci. 7(12): 2207-2214. doi: https://doi.org/10.20546/ijcmas.2018.712.251 